\title{
Media Framing of Minorities' Crisis: A Study on Aljazeera and BBC News Coverage of the Rohingya
}

\author{
OSAMA KANAKER \\ MOHAMED OKLAH ABUGHAZLIH \\ MOHD FAIZAL KASMANI \\ Universiti Sains Islam Malaysia
}

\begin{abstract}
News nowadays is framed according to its makers. A single news item can be presented in different frames. The Rohingya are currently considered one of the most oppressed minorities worldwide. However, this minority did not receive enough support to alleviate their crisis. In this article framing theory is implemented to discover the frames used by Aljazeera and BBC in framing the causes and ramifications of the Rohingya crisis. This paper found out that news covered six main causes of the Rohingya crisis. The prominent cause that both Aljazeera and BBC agreed upon was security and military causes. $91.8 \%$ of the coverage was allocated to this prominent cause. The remaining $8.2 \%$ was for the other causes. Concerning ramifications, it was found out that news of Aljazeera and BBC collectively covered 20 ramifications. The majority of the ramifications were covered by both Aljazeera and BBC. However, Aljazeera independently cover 17 ramifications and the BBC independently covered only 10 ramifications. The main three ramifications that framed both Aljazeera and BBC news were deportation, mass massacres and oppression. Throughout the news observation, both Aljazeera and $B B C$ framed their news by focusing on detailed incidents rather than establishing a holistic picture of the crisis. The frames implemented by Aljazeera and BBC were mainly the powerlessness frame and marginally the responsibility frame.
\end{abstract}

Keywords: News, framing, Rohingya, Aljazeera, BBC.

\section{INTRODUCTION}

Every day many important events occur around the world, but only some of them are reported in the news media. People are interested in news because they like to be in the loop (Kim, Mohammad \& Fatin, 2017). Among the important events that happen is the oppression of minorities. In many countries worldwide, minorities suffer multiple social, political, economic and religious problems irrespective of the fact that many of these minorities are indigenous (Marsad Al-Azhar, 2016). Muslim minorities, in general, suffer challenges of beliefs, values, behavior, personality and knowledge posed by the non-Islamic environment they live in (Attawab, 2012). One of these minorities is the Rohingya minority of Myanmar.

The Rohingya minority lives in the Muslim region of Arakan in southwestern Myanmar (Khdr, 2008; Shadeed, 2015). Their population reaches four million Muslims forming $70 \%$ of the population of Arakan. The Muslim population of Arakan is called Rohingya. Some researchers believe that the Rohingya confessed the faith of Islam long time ago since the Rashidun Caliphate. Other researchers believe that Islam entered the region during the Umayyad era (Ibrahim, 1996). A third group of researchers such as Phayre (1883) believe that it was during the Abbasid era. No matter during which caliphate of the three Islam reached the Rohingya, the three of them were long time ago. It did not exceed the second century $A H$ until Islam was known in that country. 
In the year $44 \mathrm{AH} / 664 \mathrm{AD}$ Muslims entered the west of Burma (Arakan province) through Arab merchants (Ibrahim, 1996). It is reported that mosques and Islamic centers were seen on the coasts of Arakan and the banks of the Bay of Bengal just fifty (50) years after the commissioning of Prophet Muhammad (PBBUH), (Harvey, 1925). Early Muslims established mosques and schools and among them is the curious Mosques known as Buddermokan (Harvey, 1925) which are recently known as the shrines of Badr. Then Islam spread in different areas of Burma.

Some historians argue that Islam arrived in Arakan during the reign of the Abbasid caliph Harun al-Rashid in the eighth century AD by the Arab merchants, and then followed by Islamic delegations from around the globe. Then a large number of people reverted to Islam (Aal-Fa'iz, 1986; Phayre, 1883). Other researchers believe that Muslims ruled themselves in the Arakan Kingdom from the beginning of Islam in that region until 1084 AD (Aal-Fa'iz, 1991). Then Muslims regained power in the kingdom of the Rohingya for 354 years from 1430 AD until 1784 AD when Burma occupied it (Annadawi 2002). It was also stated that the kingdom was from 1404 AD to 1785 AD (Aal-Fa'iz, 1991). The ancient maps showed the name of Arakan as an independent entity, including an ancient map of Asia drawn by the Portuguese in 1750, showing Arakan between India and the Burmese Kingdom of Pegu.

The Rohingya Muslims of Myanmar are one of the gravely oppressed minorities in the world (Al-'Nizi, 2013; Shadeed 2015). They belong to Moroccan, Persian, Turkish and Bengali origins, and their ethnic origin dates back to the first half of the seventh century AD (Aal-Fa' $i z$, 1986). Muslims have to be alert of the agonies that the Rohingya minority experience in order to contribute to the formation of an Islamic and international public opinion that will help to take international actions towards this humanitarian disaster. Several conferences and seminars have been held to discuss the problems of Muslim minorities such as the conference held in Mecca on October 20-21st, 2012. However, the crisis persisted because no genuine procedures were taken by the concerned international authorities. This situation contributed to the persistence of the crisis.

Based on the discussion above, the Rohingya minority has a historical right to the land of Arakan. However, this inherent right is under-represented or misframed by the media. The representation of the Rohingya minority in the news is almost limited to struggle and suffering. The right of independence or attaining a decent life in the region of Arakan is hardly addressed.

\section{RESEARCH BACKGROUND}

According to the United Nations human rights (2010) Minorities are identified based on national or ethnic, cultural, religious and linguistic identity, and provides that States should protect their existence. Minorities sometimes are not welcomed in the societies they live in. Therefore, these unwelcomed minorities may experience, discrimination, revenge, lack of human rights, deportation or even homicide. The Rohingya minority is facing that.

The Rohingya crisis is one of the most recent crisis in the world (Rahman et al., 2018). The term 'Rohingya' is widely used to describe Muslims who reside in the region of Arakan. The term is also used to describe all Muslims in Burma (Khdr, 2008; Shadeed, 2015). The crisis, which takes the form of conflict, arises chiefly from the religious differentiation between the Rakhine Buddhists and Rohingya Muslims. The recent Rohingya ethnic violence in Rakhine state of Myanmar increased and it was transformed into ethnic cleansing and genocide (Nawoyski, 2013). 
Rahman et al. (2018) state that, Rohingya means inhabitants of Rohang, people of the community who have been living in Myanmar from thousands of years. The Rohang is actually a Bengali word used by Bengali Muslims in the 17th century to identify the Kingdom of Arakan which is now kwon as Rakhine. The Kingdom was later occupied in 1785 by the Burmese. The predicament of the Rohingya Muslims has persisted over the last three decades, which brutally deteriorated in the last few years. In the time between 1948 and 1962, the Rohingya were treated as citizens after the independence of Burma by three successive governments. Though the Rohingya are concentrated in the Arakan region, there is no solid information about the indigenous people of Arakan. However, archeologists believe that the Rakhaine started living ther in 3000 BCE.

According to Mohajan (2018) in his study, History of Rakhine State and the Origin of the Rohingya Muslims, states that the Rohingya, a Muslim ethnic minority group in Rakhine, are considered among the most persecuted, vulnerable, and oppressed minorities in the world. Recently, the persecution on the Rohingya Muslims has increased due to Buddhist nationalism in Myanmar. The Rohingya continue to suffer from several forms of restrictions and human rights violations in Myanmar due to them being denied Myanmar citizenship.

The UNHCR (2017) reported that approximately 1 million stateless people resided in Rakhine State prior to 25 August 2017, almost all of whom were Muslims who are selfidentified as Rohingya. They were born and raised in Myanmar for multiple generations, and know no other place to call home. The same UNHCR report testified that as a direct result of their statelessness, the Rohingya suffer serious limitations on their enjoyment of basic human rights. There is an inseparable link between the serious discrimination, marginalisation, denial of a wide range of basic rights and the deprivation of citizenship. Hossain and Hosain (2019) further argue that discriminatory policies of Myanmar's government since the late 1970s have compelled hundreds of thousands of Muslim Rohingya to flee their homes in the predominantly Buddhist country [1-3]. Most have crossed by land into Bangladesh, while others have taken to the sea to reach Indonesia, Malaysia, and Thailand.

Previous literature has studied the Rohingya crisis from different angles. Knuters (2018), for example, studied the political Buddhism and the exclusion of Rohingya in Myanmar. Ullah (2016) studied the Rohingya crisis focusing on human right issues. He tried to seek justice for the stateless Rohingya by studying 29 Rohingya refugees in three main refuge destinations: Bangladesh, six; Thailand, 14; and Malaysia, nine. Of them, four were women (three in Thailand and one in Malaysia). Also, Brooten (2015) studied the framing coverage of violence against the Rohingya in Myanmar. This study analyses a series of 2013 Reuters investigative reports on the Rohingya that won the 2014 Pulitzer Prize, and a series of blog posts that further the story appearing in English language transnational media.

Moreover, Haque (2018) discussed the socio-political impacts of Rohingya refugees on Bangladesh. The main ramifications of the crisis were multidimensional sociopolitical problems like environment degradation, human trafficking, prostitution and recruitment of Rohingya. Rahman et al. (2018) studied the identity of the Rohingya in Myanmar. They proved that the Rohingya have been a part of long history of Burma. Also, Hossain and Hosain (2019) studied the Rohingya identity crisis. They collected data though direct interviews with the refugees. At the end, the authors urged international communities to assist solving this crisis. Based on the above literature, a gap for settling the crisis remains unattended. 
Although news framing has been covered recently in literature (Provencher, 2016; Borah, 2011; Cissel, 2012; Mohammad Noorhusni \& Abd Rasid, 2017; Rasaq, Rosli \& Mohd. Khairie, 2016), there remains a shortage of publications addressing news framing covering the Rohingya crisis. A need for more research is recommended by Hossain and Hosain (2019) on settling the Rohingya crisis. Afzal (2016) also stated the need for more future studies on analysing the media coverage of the Rohingya crisis to settle it.

\section{NEWS FRAMING}

The concept of framing was first posited by Gregory Bateson in 1972. The basis of framing theory is that the media focuses attention on certain events and then places them within a field of meaning (Arowolo, 2017). Framing is a symbolic expression that uses words or visuals to create a pattern or a categorization in the audiences' minds (Azahar \& Adibah, 2018). Frames provide meaning through selective simplification, by filtering people's perceptions and providing them with certain information regarding a certain issue (Razer \& Friedman, 2017). The term frame is commonly used to indicate the way news frames and creates news stories and the way media present the information they convey and construct values for audiences (Arowolo, 2017; An \& Gower, 2009; Chong \& Druckman, 2007). A media frame or a frame in communication refers to the words, images, phrases, and presentation styles that speakers or media use to convey information or certain messages to audiences (Chong \& Druckman, 2007; Cissel, 2012; Vreese, 2005).

Framing, as a theory in mass communication studies is one of the oldest and most well-established concepts (Pere, 2013; Ardèvol-Abreu, 2015). Much of the research on framing has focused on media frames (An \& Gower, 2009; Weaver, 2007). A large and growing body of mass media research centers on the concept of framing (D'Angelo, 2006). Many communication studies depend on framing theory to discover the frames used by newsrooms and journalist prior to releasing them to the audience. In framing theory, some studies focus on frame building. These studies are concerned with how frames create understanding of news and issues, and focus on the frames adopted by newsrooms and journalists. Other studies focus on frame setting. They are concerned with the way media framing influences their audiences when they are exposed to news.

In communication, framing defines the way news media coverage shapes mass opinion by using these specific frameworks to help guide their audience to understanding (Cissel, 2012). Frames lead audiences to accept one meaning over another. Media frames provide boundaries around a news story and determine what is and is not newsworthy or notable. A frame also refers to the way media as gatekeepers organise and present the ideas, events, and topics they cover. A single news story can be presented in multiple forms based on the perception, attitudes and preferences of the news source. For example, at least three presentational styles can be developed when presenting a crisis news story. First, international bodies can be blamed because they did not put an end to the crisis. Second, local government who allowed the crisis to happen can also be blamed. Third, the oppressing majority can also be blamed. Therefore, it is significant to discover the frames that media use to present a crisis event (An \& Gower, 2009).

Reviewing the literature shows that media utilise multiple frames in covering news. For example, Ryabinska (2007) identified six news frames: conflict, economic consequences, human impact, responsibility, morality and powerlessness frames. The conflict frame refers to the practice of reporting stories of clashing interpretation (Neuman, Russell \& Ann, 1992). Economic consequences frame is the frame that reports an event, problem, or issue in terms 
of the consequences it will have economically on an individual, groups, organisations or countries (An \& Gower, 2009). The human impact frame focused on descriptions of individuals and groups affected by an issue (Vreese, 2005). The responsibility frame attributes responsibility to political institutions or individuals (Ryabinska, 2007). The morality frame puts the event, problem or issue in the context of morals, social prescriptions and religious tenets (An \& Gower, 2009). The powerlessness frame refers to the oppression and dominance of forces over weak groups or individuals (Neuman, Russell \& Ann, 1992). To discover the frames utilised by Aljazeera and BBC in framing the causes and ramifications of the Rohingya crisis, the framing theory was utilised.

\section{METHODOLOGY}

This paper is a content analysis study that implements the quantitative method. It aims at obtaining quantitative results from content analysis of two Arabic TV channels (Aljazeera \& $B B C$ ). The unit of analysis is the related news topics reported within the period of the study to enable obtaining a holistic understanding of the news. Aljazeera and BBC were chosen because they are international channels famous of their extensive coverage of the Rohingya issue compared to other channels. Aljazeera encourages political action against oppression of Muslims (Entman, 2019). It continuously covered the Rohingya minority crisis since 2012 until the time of this study. Al Jazeera testified on its website that in 2017 it was ranked the sixth best news agency worldwide. The BBC has an office in Myanmar that enabled it to cover the crisis closely. Besides, the BBC Arabic channel obtained a large number of online viewers which reached more than 21 million a month. In addition, the regular users are about one and a half million. Besides, Aljazeera and BBC are international channels that cover news internationally not like local channels whose main concern is local news. The sample of the study is the whole year of 2017. The main daily news bulletin was taken only. The bulletin was obtained from the channels' websites. Throughout the year of 2017, only 122 news bulletin of Aljazeera and 50 of BBC reported the Rohingya minority crisis.

A coding sheet was created benefitting from previous content analysis studies of wars and conflicts such as Al-Baghdadi (2010), Adwan (2012) and Ma'iuf (2014) as well as other content analysis studies like Kanaker and Zulkiple (2016) with Kanaker, Rosidayu, Suria and Salah (2017). The objective of this study is to discover the frames used by Aljazeera and BBC in framing the causes and ramifications of the Rohingya crisis. To achieve this objective, frequency, percentage and chi-square were run. Intercoder reliability was also implemented to ensure the accuracy of the data. Three coders run the coding independently. Then, Holsti's formula was implemented to test the intercoder reliability. The first coder result was $(90.1 \%)$, the second was (92.3\%) and the third was (88\%). The intercoder agreement between the first and second coders was (91.2\%). The intercoder agreement between the first and third coders was (89.05\%). The intercoder agreement between second and third coders was (90.15\%). The final intercoder agreement among the three coders was $(90.1 \%)$.

\section{RESULTS AND DISCUSSION}

This study, as mentioned above, is meant to discover the causes and ramification of the Rohingya crisis as framed by the Aljazeera and BBC. Accordingly, the results are divided into causes and ramifications. 


\section{a. Causes of the Rohingya Crisis}

To find out the causes of the crisis as framed by Aljazeera and BBC, 365 main daily news bulletins of 2017 were observed. Throughout the year of 2017, Aljazeera covered (122) incidents while BBC covered only (50). If the same news items were repeated, they are considered only one. Frequencies of the causes and their percentages and chi-square were measured. The results are shown in table 1 below.

Table 1: Causes of the Rohingya crisis as framed by Aljazeera and BBC

\begin{tabular}{|c|c|c|c|c|c|c|c|}
\hline \multirow[b]{2}{*}{ No. } & \multirow[b]{2}{*}{ Causes } & \multicolumn{2}{|c|}{ Aljazeera } & \multicolumn{2}{|c|}{ BBC } & \multicolumn{2}{|c|}{ Total } \\
\hline & & Frequency & $\begin{array}{c}\text { Percentage } \\
\text { (\%) }\end{array}$ & Frequency & $\begin{array}{c}\text { Percentage } \\
\text { (\%) }\end{array}$ & Frequency & $\begin{array}{c}\text { Percentage } \\
\text { (\%) }\end{array}$ \\
\hline 1 & $\begin{array}{c}\text { Security \& } \\
\text { Military }\end{array}$ & 110 & $90.2 \%$ & 48 & $96 \%$ & 158 & $91.8 \%$ \\
\hline 2 & Religion & 5 & $4.1 \%$ & 1 & $2 \%$ & 6 & $3.5 \%$ \\
\hline 3 & Politics & 3 & $2.5 \%$ & 0 & $0 \%$ & 3 & $1.7 \%$ \\
\hline 4 & Economy & 2 & $1.6 \%$ & 0 & $0 \%$ & 2 & $1.2 \%$ \\
\hline 5 & United Nations & 1 & $0.8 \%$ & 1 & $2 \%$ & 2 & $1.2 \%$ \\
\hline 6 & Culture & 1 & $0.8 \%$ & 0 & $0 \%$ & 1 & $0.6 \%$ \\
\hline 7 & International & 0 & $0 \%$ & 0 & $0 \%$ & 0 & $0 \%$ \\
\hline 8 & Media & 0 & $0 \%$ & 0 & $0 \%$ & 0 & $0 \%$ \\
\hline \multirow[t]{2}{*}{9} & Society & 0 & $0 \%$ & 0 & $0 \%$ & 0 & $0 \%$ \\
\hline & Subtotal & 122 & $100 \%$ & 50 & $100 \%$ & 172 & $100 \%$ \\
\hline
\end{tabular}

It is noticeable from the table above that the security and military causes obtained the highest score. Aljazeera scored (90.2\%) and BBC scored (96\%). The average percentage of both Aljazeera and BBC was (91.8\%). The Myanmar government military campaign was promoted as a campaign to defend the country and establish peace. It is also promoted as a reaction to attacks by members of the Rohingya factions. Therefore, the Myanmar government was able to justify its campaign. Consequently, the calamities of the campaign are promoted as conflict not aggression or ethnic cleansing.

Religion was the second highest score with minor percentage of only (4.1\%) on Aljazeera and (2\%) on BBC. The total percentage of both channels combined was (3.5\%). Even though religion might appear to be the main cause of the conflict, it scored a very low percentage. It might be due to the international laws that affirms the freedom of belief. Therefore, the crisis was not portrayed as a religious conflict. However, it is important to address the Rohingya crisis as a religious and ethnic minority that faces systematic persecution by a state ruled by a different religion majority that enforces security grip and deploys military forces against unarmed Rohingya Muslims. The other seven remaining causes obtained very minimal scores. The scores of both Aljazeera and BBC were ranged between ( 0 $-1.7 \%)$.

The significant focus on the security and military cause rather than religion and race is a marginalisation and deviation from the inherent impulse of the ethnic cleansing of the Rohingya minority carried out by Myanmar. The intrinsic cause of the crisis is religion and race because Buddhist religious men were allowed to practice their incitement mainly the 969 movement, which is a Buddhist movement opposed to what they see as Islam's expansion in predominantly-Buddhist Burma. Ashin Wirathu who is a Burmese Buddhist monk and the leader of the anti-Muslim movement in Myanmar, for example, was released in 2011 and allowed to pursue his activities in spreading hatred among Buddhists and Muslims in Myanmar. 
To discover the existence of a significant difference between Aljazeera and BBC framing of the crisis causes, the chi-square test was run. Table 2 shows no significant difference took place between both channels.

Table 2: Differences of Rohingya crisis causes

\begin{tabular}{cccc}
\hline \multirow{2}{*}{ Causes } & Chi-square & Degrees of freedom (d.f.) & P-value \\
\cline { 2 - 4 } & 3.463 & 5 & 0.629 \\
\hline
\end{tabular}

\section{b. Ramifications of the Rohingya Crisis}

To discover the ramifications of the crisis as framed by Aljazeera and BBC, the news coverage was observed. The ramifications were categorised. Then, frequency, percentage and chisquare were measured as shown in table 2.

Table 3: Ramification of the Rohingya crisis as framed by Aljazeera and BBC

\begin{tabular}{|c|c|c|c|c|c|c|c|}
\hline \multirow[b]{2}{*}{ No. } & \multirow[b]{2}{*}{ Ramifications } & \multicolumn{2}{|c|}{ Aljazeera } & \multicolumn{2}{|c|}{ BBC } & \multicolumn{2}{|c|}{ Total } \\
\hline & & Frequency & $\begin{array}{c}\text { Percentage } \\
\text { (\%) }\end{array}$ & Frequency & $\begin{array}{c}\text { Percentage } \\
(\%)\end{array}$ & Frequency & $\begin{array}{c}\text { Percentage } \\
(\%)\end{array}$ \\
\hline 1 & Deportation & 40 & $32.8 \%$ & 29 & $58 \%$ & 69 & $40.1 \%$ \\
\hline 2 & Mass massacres & 19 & $15.6 \%$ & 5 & $10 \%$ & 24 & $14 \%$ \\
\hline 3 & Oppression & 19 & $15.6 \%$ & 3 & $6 \%$ & 22 & $12.8 \%$ \\
\hline 4 & $\begin{array}{l}\text { Crimes against } \\
\text { humanity } \\
\text { Vandalising }\end{array}$ & 14 & $11.5 \%$ & 1 & $2 \%$ & 15 & $8.7 \%$ \\
\hline 5 & $\begin{array}{l}\text { Rohingya } \\
\text { properties }\end{array}$ & 5 & $4.1 \%$ & 2 & $4 \%$ & 7 & $4.1 \%$ \\
\hline 6 & Rape & 5 & $4.1 \%$ & 0 & $0 \%$ & 5 & $2.9 \%$ \\
\hline 7 & $\begin{array}{l}\text { Loss of political } \\
\text { rights }\end{array}$ & 4 & $3.3 \%$ & 0 & $0 \%$ & 4 & $2.3 \%$ \\
\hline 8 & Amputation & 0 & $0 \%$ & 4 & $8 \%$ & 4 & $2.3 \%$ \\
\hline 9 & $\begin{array}{l}\text { Economic } \\
\text { difficulties }\end{array}$ & 3 & $2.5 \%$ & 0 & $0 \%$ & 3 & $1.7 \%$ \\
\hline 10 & Arrest & 3 & $2.5 \%$ & 0 & $0 \%$ & 3 & $1.7 \%$ \\
\hline 11 & Drowning to death & 2 & $1.6 \%$ & 1 & $2 \%$ & 3 & $1.7 \%$ \\
\hline 12 & $\begin{array}{l}\text { Emergence of } \\
\text { resisting factions }\end{array}$ & 0 & $0 \%$ & 2 & $4 \%$ & 2 & $1.2 \%$ \\
\hline 13 & $\begin{array}{l}\text { Women become } \\
\text { subject to sexual } \\
\text { slavery }\end{array}$ & 0 & $0 \%$ & 2 & $4 \%$ & 4 & $1.2 \%$ \\
\hline 14 & $\begin{array}{l}\text { Tension and } \\
\text { attacks }\end{array}$ & 1 & $0.8 \%$ & 1 & $2 \%$ & 2 & $1.2 \%$ \\
\hline 15 & $\begin{array}{l}\text { Marginalization } \\
\text { Depriving the }\end{array}$ & 2 & $1.6 \%$ & 0 & $0 \%$ & 2 & $1.2 \%$ \\
\hline 16 & $\begin{array}{l}\text { practice of } \\
\text { religious rites }\end{array}$ & 1 & $0.8 \%$ & 0 & $0 \%$ & 1 & $0.6 \%$ \\
\hline 17 & Social insecurity & 1 & $0.8 \%$ & 0 & $0 \%$ & 1 & $0.6 \%$ \\
\hline 18 & $\begin{array}{l}\text { Assassinating } \\
\text { political figures }\end{array}$ & 1 & $0.8 \%$ & 0 & $0 \%$ & 1 & $0.6 \%$ \\
\hline 19 & Hatred & 1 & $0.8 \%$ & 0 & $0 \%$ & 1 & $0.6 \%$ \\
\hline 20 & $\begin{array}{l}\text { Health difficulties } \\
\text { Disintegration }\end{array}$ & 1 & $0.8 \%$ & 0 & $0 \%$ & 1 & $0.6 \%$ \\
\hline 21 & $\begin{array}{l}\text { between Muslims } \\
\text { and Buddhists }\end{array}$ & 0 & $0 \%$ & 0 & $0 \%$ & 0 & $0 \%$ \\
\hline & Subtotal & 122 & $100 \%$ & 50 & $100 \%$ & 172 & $100 \%$ \\
\hline
\end{tabular}


Table 3 above shows that the ramifications of the crisis did not obtain equal score. The analysis showed that deportation was the major ramification framed by Aljazeera and BBC. Aljazeera's score was (32.8\%) and BBC's was (58\%). The total score of both Aljazeera and BBC was $40.1 \%$.

This result represents the actual ramifications on the ground. The Myanmar security and military forces are acting freely without any accountability. The Rohingya are armless. They have no power for retaliation. Therefore, the only action that the civilians can take is to flee and save their lives. Deportation seems to be intended in itself. It can be enforced by several means such as murder and intimidation. Thus, killing might not be intended in itself, but it is used as a means for panic spread among the Rohingya Muslims minority to abandon their lands and source of livelihood and leave their homeland where they lived for hundreds of years.

Moreover, the Rohingya suffered violation of fundamental rights, such as freedom of speech, movement, religion, employment, and access to education-a situation made worse by additional measures taken against ethnic identity that limit their rights to get married or even to have children. Consequently, over the years Myanmar, and especially the Rakhine State, has registered an increase in the number of people fleeing the country, mainly towards safer neighboring States (Pagano, 2016). Figure 1 shows the increasing number of refugees, internally displaced persons (IDPs) and stateless people of Myanmar.

Figure 1: Refugees from Myanmar (1978-2014)

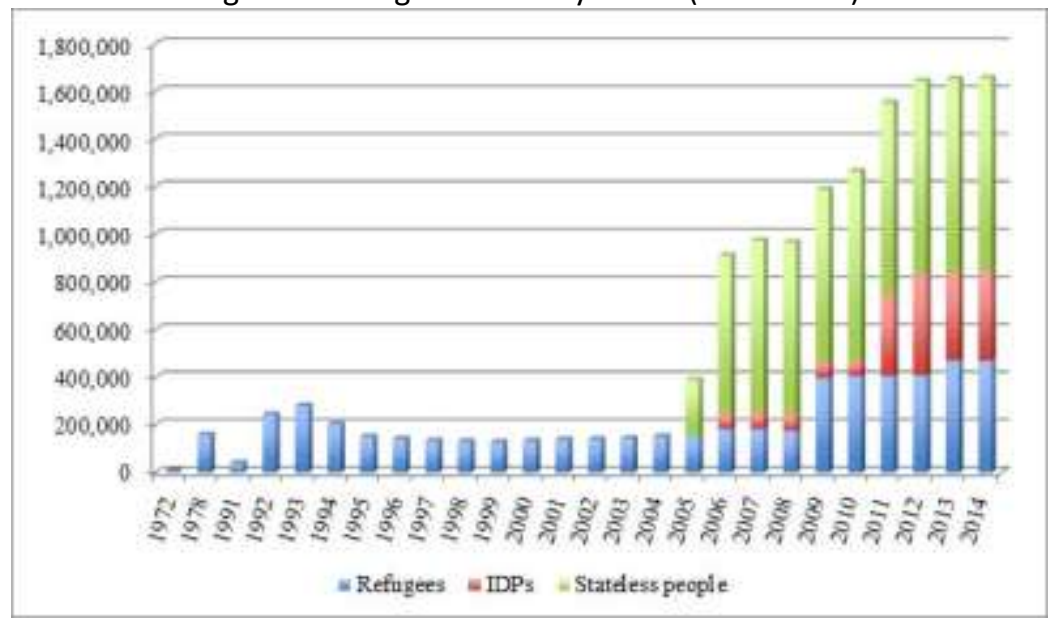

Source: United Nations High Commissioner for Refugees (U.N.H.C.R.)

Despite the fact that the figure 1 above shows data that represents refugees from all over Myanmar, it is important to notice that the departure of refugees occurred in 1978 was high. It is also the same case between 1992 \& 1994 during discriminatory measures undertaken by Burmese authorities against Rohingya minority. The data also shows that the beginning of 2005 marked a sharp and continuous rise in the number of stateless people and Internally Displaced Persons (IDPs) undoubtedly including the Rohingya minority (Pagano, 2016).

The second top ramification of the Rohingya crisis framed by Aljazeera and BBC was the mass massacres that were committed against the Muslim minority. The score of Aljazeera channel was $(15.6 \%)$ while $(10 \%)$ only was the BBC score. The total percentage of both channels was (14\%) as shown in table3 above. The close agreement between Aljazeera and $\mathrm{BBC}$ of massacres to occupy the second top category of the Rohingya crisis ramifications is 
itself an indication to the grave injustice and agonies that the Muslim Rohingya minority faced. It is also noticeable that the difference between Aljazeera and BBC scores is not highly significant. It is almost (5\%).

Oppression of the Rohingya minority occupied the third place in the coverage. (15.6\%) of Aljazeera coverage of the crisis was about oppression that the Rohingya underwent. However, BBC oppression occupied (6\%) only of its coverage. Compared to BBC, Aljazeera paid much attention in framing oppression as a ramification of the crisis. The frequency of oppression on Aljazeera was more than double of that of BBC. The fourth top category, crimes against humanity, was almost similar. It occupied (11.5\%) of Aljazeera coverage, while BBC coverage was only (2\%). The total score of both channels was (8.7\%).

However, the fifth category was almost equal in both Aljazeera and BBC. Vandalising Rohingya properties was the fifth important category of Aljazeera. Aljazeera coverage of vandalism was (4.1\%). Unlike Aljazeera, vandalism was the fourth important category of the BBC coverage of the Rohingya crisis. Vandalism on BBC scored (4\%). Vandalising Rohingya properties is placed in the fifth place because the overall score of both Aljazeera and BBC was (4.1\%) as shown in table 3 above. To cover vandalism, both channels focused on property incineration incidents and they used satellite images to confirm that.

Rape was the sixth top score of the Rohingya crisis ramifications. The total score of both Aljazeera and BBC was (2.9\%). Aljazeera covered rape issues five (5) times, while BBC never covered it. Despite numerous interviews with victims of sexual violence committed by members of the army and extremists against the Rohingya women, no real actions of human rights associations or women's rights associations that claim to defend women's rights worldwide were taken.

News coverage could have paid greater attention to rape issues by presenting certified medical reports issued by United Nations doctors or other UN organisations in order to raise the issue of these women to the international human rights bodies. It is apparent that women's rights associations around the world sometimes avert their eyes from cases of sexual slavery and extortion conducted by some human trafficking gangs. Consequently, women of different ages face an unknown and painful fate.

The seventh top ramification of the Rohingya crisis covered by Aljazeera and BBC was loss of political rights. Multiple testimonies could have been compiled to help create additional pressure on the international human rights institutions to actuate international cases against Myanmar using those testimonies that are binding in international law to confirm the Rohingya's political identity as indigenous rather than alien citizens. Based on table 3 above, amputation obtained equal score of loss of political rights (2.3\%). The low percentage might be due to sensitivity and distressfulness of such scenes. Aljazeera never broadcast any amputation scene, but BBC covered it four times only.

The ramification category of economic difficulties received only a minor percentage of Aljazeera's interest (2.5\%), but BBC never touched on it (0\%). This percentage might not represent the actual situation on the ground. However, the low score might be due to the concentration of the news on much significant issues like oppression, deportation and mass massacres. The military campaign, extremists Buddhist and the fears of deportation contribute to deterioration of the economic situation. These difficulties require the United Nations and other involved organisations to intensify their efforts in the area of military operations to provide assistance. These organisations are expected to examine the causes of the current situation and contribute to alleviate the crisis. Poor health conditions due to lack 
of health care and medicine are mentioned only once Aljazeera. It means that health and physical safety have not been a concern for the coverage which can contribute to worsening conditions that the Rohingya minority experiences.

Both arrest and drowning to death were equally covered. They obtained the same total score of economic difficulties ramifications (1.7\%). The three of them were in the eighth place. Aljazeera broadcast three incidents of arrest while BBC never mentioned it. However, $B B C$ covered a single drowning incident which Aljazeera covered two.

The ninth top ramification covered by Aljazeera and BBC was emergence of resisting factions scored only (1.2\%). As a primitive consequence of the systematic persecution against the Rohingya, some resisting factions emerged to retaliate against the persecutors. However, these factions are unknown in number, force, equipment and the actual impact they have on the ground. Due to minor information about the resisting factions, all calamities that afflicted the Rohingya are linked to them. They are even portrayed as the main cause of the massive destruction, displacement, persecution and abuse that took place. Myanmar government portrays that the military operations that resulted in killings, rapes and displacements of civilians are a reaction to the resisting factions.

Furthermore, Myanmar tries to portray these factions as perpetrators who initiate attacks on security and military forces. If this claim was true, the media would have been covered the retaliating operations of these factions who are supposed to be able to face the government of Myanmar and cause all the damage. Myanmar repeatedly tried to proof the existence of these factions on the ground to justify its military operations and abuses to be promoted as a process of conflict between the legitimate government and perpetrators. Accordingly, the unarmed civilians are described as being the factions themselves or their allies that authorizes the Myanmar government to fight them.

The three ramifications of women become subject to sexual slavery, tension and attacks and marginalization were also (1.2\%) each. Burma is composed of multiple minorities such as Buddhist and Muslim. Sexual slavery, tension and marginalization are only incited against the Muslim Rohingya minority. They are even portrayed as non-citizens of Myanmar and have to leave the country.

Furthermore, depriving the practice of religious rites is the sixteenth ramification listed in table 3 above, but it obtained the tenth rank. Its core was relatively low $(0.6 \%)$ only. In order to increase the restrictions on the Rohingya minority and to force them to flee, the Myanmar authorities have taken measures against them in order to deprive them of practicing rituals, either by demolishing a number of mosques or by arresting imams and teachers or by taking over the waqf institutions that cherish mosques and schools. Even some government decisions published by the media enforced the closure of religious schools because Friday prayers were held in their buildings after the destruction of the village mosque. The organizers of Friday prayer were also arrested. This nuisance that the Muslim Rohingya minority experiences was also accompanied by clashes between residents of the region and Buddhists supported by the security forces resulted in appropriation of property agricultural land and homes by force. The appropriation process resulted in killing of innocent people who defended their right to remain in their land.

In addition, social insecurity total score was also low. It obtained equal score with the former category (0.6). Aljazeera highlighted social insecurity in its coverage throughout the year only once $(0.8 \%)$. BBC even never touched on it $(0 \%)$. During times of war, people live under constant terror. The Rohingya are not different. They lived under continuous fear due 
to the crisis. They fear the neighboring villages that might launch attacks at any time, let alone the military threats and ongoing security raids.

Assassinating political figures, hatred and health difficulties categories were also equal. Each of them scored (0.6\%). These three categories were only covered by Aljazeera. $\mathrm{BBC}$ has never touched on them. Aljazeera broadcast a single news item on each. All these ramifications of the crisis contributed to the spread of hate speech against the Rohingya minority. It also contributed to the promotion of extremist ideas among Buddhists which opened up the way to unofficial Burmese groups to engage in atrocities against their Muslim neighbors and villagers. These unofficial groups executed terrorizing operation and practiced fear mongering among the Rohingya.

The final category of disintegration between Muslims and Buddhists was not covered at all neither by Aljazeera nor by BBC. It is surprising that an intuitive result of hatred incitement and inflammatory rhetoric against Muslims that was spread among groups of Buddhist society has not been addressed in the coverage. Despite the non-existence of social integration in the coverage, Aljazeera and BBC should have paid attention to because it might be a way to find radical solutions to the Rohingya crisis. However, it appears that the government of Myanmar is trying not to engage with any party that tries to open up a dialogue whether on the regional, South-East Asian or international levels.

To discover whether there is a significant difference between the ramifications framed by Aljazeera and BBC, chi-square was measured. See Table 4.

Table 4: Differences of Rohingya crisis ramifications

\begin{tabular}{cccc}
\hline \multirow{2}{*}{ Causes } & Chi-square & Degrees of freedom (d.f.) & P-value \\
\cline { 2 - 4 } & 41.591 & 19 & 0.002 \\
\hline
\end{tabular}

The results showed that there were significant differences between the two channels. The $p$-value was (0.002). Reviewing back the ramifications, it appeared that the significance was in the category of deportation. BBC obtained higher score compared to Aljazeera. Aljazeera score was (32.8\%), while BBC's score was (58\%). Despite the higher percentage of BBC's score, the frequency of Aljazeera was higher because Aljazeera's overall coverage of the Rohingya crisis was higher. The frequency of deportation coverage of Aljazeera was 40, while the BBC's was only 29.

\section{CONCLUSION}

Even though the widespread of news facilitated an easy access of news, it enables the spread of low-quality news (Elareshi, Alsridi \& Ziani, 2020). The content analysis of this study provides an evidence that news has the ability to shape and even create audience attitudes toward incidents that happen every day by imparting certain frames on them. The main frame used in the causes and ramifications is powerlessness. More than $90 \%$ of the causes were military and security causes. The majority of the ramifications happened because of the powerlessness of the Rohingya minority who was unable to defend themselves. The responsibility frame was marginally used in the causes of the crisis when referring to politics and the United Nations as two causes of the crisis persistence.

Aljazeera and BBC framed their news of the Rohingya minority by focusing on incidents, rather than drawing the bigger picture of the crisis. The news of the Rohingya minority crisis was framed to present struggle and agonies. It ignored the right of the Rohingya to peaceful life and recognised citizenship. On the ground, there was a systematic 
process to evacuate the indigenous Muslim minority from the region to either reduce their numbers or eradicate them completely. The aim, obviously, was to displace the Rohingya Muslims outside Arakan or even Myanmar by practicing all forms of violent aggression and gross violations against them such as mass massacres and rape of women and girls. All these acts give indications of ethnic cleansing by the Myanmar authorities.

The framing of $\mathrm{BBC}$ news revealed more interest in covering deportation issues and the afflictions that result from the crisis indicating that deportation was the most prominent ramification of the crisis. However, Aljazeera coverage was more extensive and comprehensive in covering other ramifications. Aljazeera was able to draw attention to other brutal practices in which the existence of a systematic plan of various methods was revealed. Mass massacres and oppression were covered by Aljazeera 19 times each. The category of crimes against humanity was covered 14 times. All other ramifications covered by Aljazeera indicate the existence of such a plan to empty the territory of Arakan of the Muslim population and replace them with Almag Buddhist communities.

Ironically, Aljazeera covered 122 news items, while BBC covered only 50 despite the fact that BBC has office in Myanmar while Aljazeera does not have. Aljazeera also surpassed $\mathrm{BBC}$ in its coverage of the ramifications. It covered 17 ramifications, while BBC covered only 10. The main reason of this difference is the interest of Aljazeera in minorities because Aljazeera promote itself as the voice of the voiceless.

Throughout the observation of Aljazeera and BBC news, it was noticeable that the coverage emphasised that the security and military campaign is the main cause of the Rohingya's suffering. Also, the coverage often did not provide explanations of the background of news events which might negatively affect the viewer's awareness of them, especially those who are not regular followers of news. The coverage of economic and health conditions has not been sufficiently important, resulting in a global failure to help mitigate the ramifications of the crisis. The absence of political rights of the Rohingya minority was noticeable in the coverage. It was not paid an adequate attention, though it is one of the main objectives that paved the way to eliminate the Rohingya from Myanmar.

Furthermore, the Myanmar authorities exercise clearance of the Rohingya intellectuals and political leaders through assassinations or arrests without evidences. The coverage also showed that the practices of the Myanmar authorities aimed to deprive the Rohingya minority of their religious rights to perform their faith and rituals. The government practices in Myanmar against the Rohingya minority escalated to the extent that these practices become integrated measures that aimed at total elimination of the Rohingya presence in the province of Arakan.

However, despite the repeated coverage of the continuous violations of children and women's rights, international organisations concerned with children and women's affairs remained silent and did not take action despite the long duration of the crisis and the continuous suffering of the Rohingya. The BBC concentrated mainly on deportation in its coverage whereas Aljazeera was more balanced. It did not focus on one ramification, but rather drew attention to other ramifications that shaped the tragedy of the Rohingya.

The findings of this study identify with the study of Rumaisa' and Iman (2018) which discovered that Aljazeera placed most of the issues discussed in its dialogue programs on the Rohingya crisis in the humanitarian context by focusing on inhumane treatment of the army against the powerless Rohingya minority. The findings are also consistent with the findings of Bl'alia (2006) who states that Aljazeera has its own footprint in covering human rights violations. It is expected that the findings of this study assist news organisations and reporters 
in framing minority crisis news. It may also assist audiences to critically understand the frames that shaped the crisis causes and ramifications. The results also help future researchers to gain a recent analysis of news frames of current minority crisis.

This study has contributed to the theoretical development by confirming the previous literature of news crisis framing. It also discovered the utilization of the responsibility, human impact and the powerlessness frames. The study revealed that the need of utilizing other frames in covering crisis news. Despite the economic consequences of the crisis, the economic frame was not implemented. The moral values frame was not utilized either. The immoral invasions, arsons and killings that took place necessitated the utilization of moral values frame to project the immoral and inhumane behaviors. Therefore, this study recommends media players not to limit the coverage to certain frames. The morality and economic frames are significant in cases of oppression and persecutions. Future researchers are recommended to study the actual causes of the Rohingya crisis, and whether the crisis is originated to religious antagonism.

Finally, based on the above findings, the study recommends that the Organisation of Islamic Cooperation (OIC) should include Arakan as a member of the organisation and consider it an Islamic country under occupation, just like Palestine. In that case it would become easier for members of the organisation to fulfill their obligation to their Muslim brothers. OIC could intervene with the United Nations and demand international protection, independence or even autonomy. The Arab and Muslim countries should exert pressure through the Organisation of Islamic Cooperation on the one hand and the Arab League on the other through the embassies and consulates in Myanmar. Pressure also can be exerted on the supporting countries of Myanmar such as Russia, China and India to alleviating the suffering that the Rohingya minority experiences.

To contribute solving the problem, more studies about framing of the Rohingya crisis in the media is recommended in order to assess the real performance of the media toward minorities and identify the shortcomings of the media concerning this issue. Academic studies that investigate the economic and social problems and religious persecutions resulted from the crisis are also recommended to discover the actual impact on the ground.

\section{BIODATA}

Osama Kanaker is a senior lecturer at Communication Program, Faculty of Leadership and Management, Islamic Science University of Malaysia. He is an editor and evaluator of al'Abqari journal. He has published several books and articles on Islam and communication. He has Communication and Islamic background. The field of interest is communication and Islam. Email: osama@usim.edu.my

Mohamed Oklah Abughazlih holds two PhDs. The first is in Qur'anic Sciences and the second is in Satellite Television. He was an Assistant Professor at Al-Jouf University, Jordan. Currently, he is attached to the Department of Advocacy and Islamic Media, Yarmouk University, Jordan. Email: mohamedabo2007@hotmail.com

Mohd Faizal Kasmani is currently an Associate Professor at the Communication New Media Programme, Universiti Sains Islam Malaysia and the Dean of the Faculty of Leadership and Management. His interests include journalism, political communication and Communication in Islam. Email: faizalkasmani@usim.edu.my 


\section{REFERENCES}

Aal-Fa'iz, \& Nur al-Islam bin Ja'far Ali. (1991). Al-muslimun fi Burma: Attarikh wa attahadiyat. Da'wat al-Haq, 5, 45-48.

Aal-Fa'iz, \& Nur al-Islam bin Ja'far Ali. (1986). Al-Muslimun arruhinjiun fi arakan: Mushiklatuhum assiyasiah fi al-madhi wa al-hadhir. Al-Aqaliyat al-Muslimah fi al'Alam: Thurufuha al-Mu'asirah, Aalamuha wa Aamaluha, 4, 613-616.

Adwan, A. H. (2012). Taghtiyat assahafa al-Isra'iliyah lilharb ala Ghaza 2008-2009: Dirasah tahliliyah wasfiyah muqaranah lithalath suhuf Isra'iliah (Master Research, Al-Azhar University, Gaza).

Al-Baghdadi, R. H. (2010). Al-mu'alajah al-I'lamiah fi qanatai Aljazeera wa al-Arabiyah lil'udwan al-Isra'ili ala Ghaza: Dirasah Muqaranah (Master Research, Gulf University, Bahrain).

Al-`Nizi, J. B. (2013). Muslimu Myanmar haqakq khala assitar. Kuwait: Kuwait University.

Annadawi, M. A. (2002). Almuslimun Arruhingya fi arakan wa mashakiluhum al-Jathriyah wa haluha. Islamic Conference on Muslim Rohingya crisis. Chittagong: Bangladesh.

An, S.-K., \& Gower, K. K. (2009). How do the news media frame crises? A content analysis of crisis news coverage. Public Relations Review, 35, 107-112.

Ardèvol-Abreu, A. (2015). Framing theory in communication research: Origins, development and current situation in Spain. Revista Latina de Comunicación Social, 70, 423-450.

Arowolo, O. (2017). Understanding framing theory (School of Communication, Lagos State University, Ojo, Lagos).

Attawab, I. A. (2012). Al-Aqaliat al-muslimah fi al-mujtama'at ghair al-muslimah. The 13th Holy Makkah Conference (Muslim Community: Established Versus Changing Values).

Azahar Kasim, \& Adibah Ismail (2018). Framing strategic news from the perspective of media organizations in Malaysia. Jurnal Komunikasi: Malaysian Journal of Communication, 34(1), 330-344.

Bl'alia, al-Z. (2006). Attaghtiyah al-I'lamiyah liharb al-Khaleej Athalitha min khilal qanat Aljazeera min 20 March 2003 ila 9 April 2003 (Master Research, University of Algiers, Algeria).

Borah, P. (2011). Conceptual issues in framing theory: A systematic examination of a decade's literature. Journal of Communication, 61, 246-263.

Brooten, L. (2015). Blind spots in human rights coverage: Framing violence against the Rohingya in Myanmar/Burma. Popular Communication. doi: 10.1080/15405702.2015.1021466

Chong, D., \& Druckman, J. N. (2007). A theory of framing and opinion formation in competitive elite environments. Journal of Communication, 57, 99-118.

Chong, D., \& Druckman, J. N. (2007). Framing theory. Annual Reviews, 10, 103-126.

Cissel, M. (2012). Media framing: A comparative content analysis on mainstream and alternative news coverage of occupy wall street. The Elon Journal of Undergraduate Research in Communications, 3(1), 67-77.

D'Angelo, P. (2006). News framing as a multiparadigmatic research program: A response to Entman. Journal of Communication, 52(4), 870-888.

Elareshi, M., Alsridi, H., \& Ziani, A.-K. (2020). Perceptions of online academics' and AlJazeera.net's news coverage of the Egyptian political transformation 2013-2014. Jurnal Komunikasi: Malaysian Journal of Communication, 36(1), 124-146.

Entman, R. M. (2019). Fridays of rage: Al Jazeera, the Arab Spring, and political Islam. Journal of Communication, 69(3), E1-E3. 
Harvey, G. E. (1925). History of Burma. London: Longsmans.

Haque, E. (2018). Socio-political impacts of Rohingya refugees on Bangladesh. Migration Policy Center: Ankara.

Hossain, S., \& Hosain, S. (2019). Rohingya identity crisis: A case study. Saudi Journal of Humanities and Social Sciences 01 May, 238-243.

Ibrahim Ibrahim Abdelfattah. (1996). Al-'alam al-Islamic fi matla' al-Qarn al-'ishreen al-hijri. Alexandria: N.P. 1.

Kanaker, O., Rosidayu Sabran, Suria Hani A. Rahman, \& Salah Mohamed Zaki Ibrahim. (2017). Authenticity of characters portrayal in Islamic films: A study on the message. Al-'abqari Journal, 12(Special Edition), 47-57.

Kanaker, O., \& Zulkiple A. Ghani. (2016). Programs analysis of Islamic - Based television the experience of al-Hijrah Malaysian television. Advances in Natural and Applied Sciences Journal, 10(2), 36-45.

Khdr, Z. M. (2008). Hadhir al-'alam al-Islami. Hail: Dar al-Andalus linnashr wa attawzi'.

Kim Hua Tan, Mohammad Abdollahi-Guilani, \& Fatin Nazihah Ahamad Rusly. (2017). Negativity as criteria for newsworthiness in Malaysian newspaper sports corpus. Jurnal Komunikasi: Malaysian Journal of Communication, 33(2), 105-119.

Knuters, S. (2018). Exploring targeted religious nationalism using Myanmar's Muslim Rohingya minority as a case study (Master's Thesis, Universitetslektor Helen Lindberg).

Ma'iuf, A. M. (2014). Ma'aiyyr attaghtiya al-ikhbariah fi al-qanawat atilfizyuniah. Al-Balqa Journal for Research and Studies, 17(1), 165-189.

Marsad Al-Azhar Billughat Alajnabiah. (2016). Muslimi Burma. Cairo: Alazhar University.

Mohajan, H. K. (2018). History of Rakhine State and the origin of the Rohingya Muslims. Premier University: Chittagong.

Mohammad Noorhusni Mohd Zaini, \& Abd Rasid Abd Rahman. (2017). Frame contention in different types of media Ownership - A comparison between The Star Online and Sinar Online's media coverage on 2017 budget. Journal of Media and Information Warfare, 9, 139-178.

Nawoyski, K. (2013). Genocide emergency: Violence against the Rohingya and other Muslims in Myanmar. Genocide Watch.

Neuman, W., Russell, Marion R. Just, \& Ann N. Crigler. (1992). Common knowledge. News and the construction of political meaning. Chicago: The University of Chicago Press.

Pere, S. (2013). Of minorities, media and misinformation: A framing analysis of the U.S. news media coverage of the Wisconsin Sikh Temple shootings. Columbia: University of Missouri.

Phayre, A. P. (1883). History of Burma. London: Trubner \& Co., Ludgate Hill.

Provencher, J. Z. (2016). Is scholarship advancing?: An analysis of fifteen years of framing research (Dissertations and Theses, Paper 2705, Portland State University).

Rahman, Md Z., Anusara, J., Chanthamith, B., Hossain, S., \& Al-Amin, Md. (2018). Rohingya crisis: Identity of Rohingya Muslim in Myanmar. International Research Journal of Social Sciences, 7(12), 12-16.

Rasaq Muhammed Adisa, Rosli Mohammed, \& Mohd. Khairie Ahmad (2016). Issues and consequences of newspaper framing on ethnic conflict: A qualitative study of ethnic group leaders' conflict frames. Jurnal Komunikasi: Malaysian Journal of Communication, 32(2), 294-316. 
Razer, M., \& Friedman, V. J. (2017). From exclusion to excellence: Building restorative relationships to create inclusive schools. Netherlands: Sense Publishers.

Rumaisa', K., \& Iman, M. (2018). Al-mu'alajah al-i'lamiyah liazmat al-aqaliah al-Muslimah Arruhingya: Dirasah Muqaranah limajmu'ah mina al-qanawat attiliziyuniah (Master Research, Université Kasdi Merbah Ouargla, Algeria).

Ryabinska, N. (2007). News framing in post-communist press: Engagement and control or disengagement and powerlessness?. Global Media Journal, Polish Edition No 1(3), 11 33.

Shadeed, T. (2015). Al-Rohingya fi Mynmar al-aqaliah al-akthar idhihadan fi al-alam. International Association International Gulf Organizaion (ialGO).

The United Nations High Commissioner for Refugees (UNHCR). (2017). Statelessness and the Rohingya Crisis. Retrieved from https://www.refworld.org/pdfid/5a05b4664.pdf

Ullah, A. K. M. A. (2016). Rohingya crisis in Myanmar: Seeking justice for the "stateless". Journal of Contemporary Criminal Justice, 32(3), 285-301.

United Nations Human Rights. (2010). Minority rights. New York and Geneva: International standards and guidance for implementation.

Vreese, C. H. de. (2005). News framing: Theory and typology. Information Design Journal, 13(1), 51-62.

Weaver, D. H. (2007). Thoughts on agenda setting, framing, and priming. Journal of Communication, 57, 142-147. 